\title{
鉱油及び溶融無機塩の熱伝達率と温度及び動粘性係数に関する実験的研究
}

\author{
荒谷眞一・佐藤恭三* \\ セントラル硝子(株), 101 東京都千代田区神田錦町 3-7-1 \\ *東北学院大学工学部，985 宮城県多賀城市中央 1-13-1
}

\section{Experimental Study of Heat Transfer Coefficient with Temperature and Kinematic Viscosity on Mineral Oil and Molten Salt}

\author{
Shin'ichi ARATANI and Kyozo SATO* \\ Central Glass Co., Ltd., 3-7-1, Kanda Nishiki-cho, Chiyoda-ku, Tokyo 101 \\ *Tohoku Gakuin University, 1-13-1, Chuo, Tagajo-shi, Miyagi 985
}

[Received September 29, 1994; Accepted January 19, 1995]

To develop a tempered glass under $3 \mathrm{~mm}$ in thickness, boiling heat transfer characteristics of mineral oil and molten salt were studied experimentally. Heat flux and heat transfer coefficient with temperature and kinematics viscosity were measured using a copper disk of $\mathbf{4 0}$ $\mathrm{mm}$ in diameter and $3 \mathrm{~mm}$ in thickness. As a result, silicone oil showed no burn out point in this experimental condition and this tendency is different from another type of oils.

Key-words : Heat transfer coefficient, Heat flux, Mineral oil, Molten salt, Glass quenching, Kinematic viscosity, Boiling heat transfer

\section{1. 緒 言}

熱強化ガラスはその破壊強度が増加すること, 及び破壊 時に角のない丸い断片となることから安全ガラスとして広 く世の中で使われている. 熱強化ガラスの安全性を高める 研究については数多くの報告があり, 著者ら ${ }^{1,2)}$ も熱強化 ガラス板におけるクラックの伝ぱ現象に関して報告してい る. 一方, 省資源 ·省エネルギーの観点から熱強化ガラス の薄板化が望まれている. 従来の熱強化ガラスとほとんど 同様の特性をもって薄板化ができれば，ガラス材そのもの の削減やビル用空ガラスの重量削減, 自動車では空ガラス の軽量化に伴う燃料の節約を始めとする多くの社会的メ リットが期待できる.

一般に，熱強化ガラスは軟化点温度近くまで加熱された 後, エア（衝突空気噴流）によって表面から急冷すること により作られる．したがって，熱強化ガラスを薄板化して いくうえで冷却媒体からの熱伝達は極めて重要な因子と なっている，同時にガラスは代表的な脆性材料であり，急 冷に対しては割れやクラックの発生防止などの厳密な管理 が必要である．急冷時に発生する過渡熱応力については例 えば高津 ${ }^{3)}$ が Maxwell model の概念を応用した計算手法 を提案している.この過渡熱応力がガラスが持っている本 来の強度よりも大きければ割れやクラックの発生につなが ることになる.

冷却媒体としては大半の生産に使われているエアのほか
にも鉱油, シリコーン油, 溶融無機塩, 溶融金属, 水の噴 霧流など，多くのものが提案されている4) 8). ガラス以 外の物質を対象にした研究は数多くなされており，参考に できる報告も多い，例えば，鉱油における沸騰熱伝達の現 象については，橘と塩治9)がスピンドル油や焼入油におけ る熱流束の実験值を報告しており，更に鉱油や水に乳化剂 を添加することにより任意の熱流束を得ることができると 述べている. 佐藤 ${ }^{10)} も$ スピンドル油やタービン油と水を 混合させることにより，任意の熱伝達率を得ることができ ると報告している.しかし，これらの冷却媒体を使っても すぐに熱強化ガラスの製造にそのまま利用できるとは言い がたい。この実験は再現性に乏しく，熱流束曲線について も測定者により実験值のばらつきがあり，その值が十分に 把握されているとは言えない面がある．ガラスのように熱 伝導率が小さな物質に対して従来の知見をそのまま応用で きるかどうかについても疑問の余地がある11),12).ガラス 板の熱強化を考慮した急冷については，冷却媒体の熱流束 測定から見直す必要があるのが現状である。

そこで，薄板強化ガラスの製造方法の一つとして考えら れている浸漬強化法に着目し，その冷却媒体として考えら れている物質の熱伝達について一連の測定を行ってみた。 本報では，市販されている鉱油，溶融無機塩，鉱油の混合 系における影響について熱流束, 熱伝達率, 液体温度（動 粘性係数）などを実験的に検討した結果を報告する.

\section{2. 実験方法及び装置}

\section{1 実験装置}

実験装置の概略を図 1 に示す。測定に使用した銅円板の 大きさは $40 \mathrm{~mm} \phi \times 3 \mathrm{~mm}$ で，その中心部には外径 $1 \mathrm{~mm}$ のシース型クロメルーアルメル熱電対温度計（露出タイプ） が固定されている．この銅円板を電気炉で約 $5 \mathrm{~min}$ 加熱 した後，ただちに供試液の中に浸漬した．データの記録は 冷接点を介在させた $x-y-t$ レコーダーにより行った。応答 が早い場合にはウェーブメモリーもあわせて用いたので， 本実験では時間的な遅れはないと考えて差しつかえない。 なお，銅円板の表面状態を一定にするために，180番のサ ンドペーパーで 1 回ごとに研磨した. 


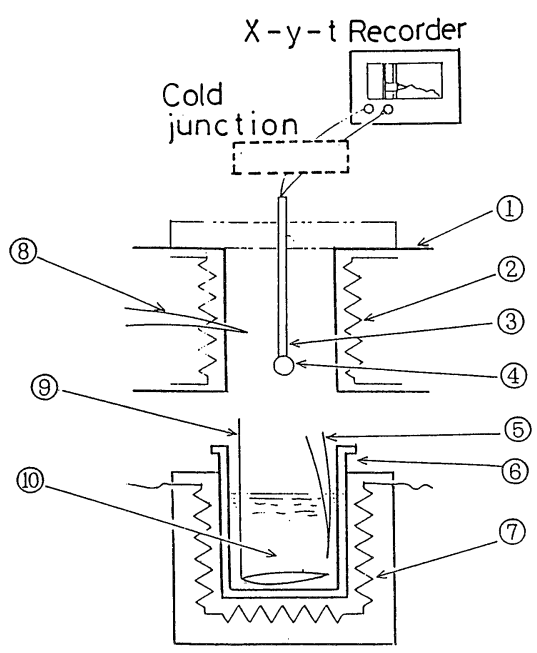
(1) Furnace
(6) Vesse1
(2) Heater
(7) Mantle healer
(3) C-A sheathed T.C. (8) C-A T.C.
(4) Copper plate
(9) Stirrer
(5) C-A T.C.
(1D) Liquid (0.i1)

Fig. 1. Experimental set-up.

\section{2 冷却媒体}

供試液としては表 1 に示す 5 種の鉱油（コンプレッサー 油, マシン油, シリコーン油）と無機硝酸塩 $\left(70 \mathrm{KNO}_{3}+\right.$ $15 \mathrm{NaNO}_{3}+15 \mathrm{NaNO}_{2}$ ) を用いた。鉱油の混合系について も測定を実施した.

\section{3 解析方法及び補正}

熱流束あるいは熱伝達率はまず銅円板における中心温度 の経時変化，すなわち冷却曲線を求め，その值から熱伝導 の逆問題として解析した．マシン油の場合における冷却曲
線の一例を図 2 に示す. 本実験ではガラス板の冷却を対象 としているので, 厚さの薄い無限平板とみなすことがで き, 一次元の熱伝導問題として取り扱って差しつかえない. Biot 数が $B i \ll 0.1$ の場合には以下の基礎方程式

$$
\frac{\mathrm{d} Q}{\mathrm{~d} t}=h A\left(T-T_{\mathrm{L}}\right)=C w \frac{\mathrm{d} T}{\mathrm{~d} t}
$$

から熱伝達率を近似的に求めた.ここで， $Q$ は伝熱量, $t$ は時間, $h$ は熱伝達率, $A$ は伝熱面積, $T$ は温度, $T_{\mathrm{L}}$ は 供試液温度， $C$ は銅円板の比熱， $w$ は銅円板の質量であ る. また， $B i>0.10$ 場合にはフーリエの一次元熱伝導方 程式

$$
\frac{\partial^{2} T}{\partial x^{2}}=\frac{1}{a} \frac{\partial T}{\partial t}
$$

を，以下の初期条件及び境界条件

$$
\begin{aligned}
& T-T_{\mathrm{L}}=T_{\mathrm{i}}-T_{\mathrm{L}} \quad \text { at } t=0 \\
& \frac{\partial\left(T-T_{\mathrm{L}}\right)}{\partial x}=0 \quad \text { at } x=0 \\
& -k \frac{\partial\left(T-T_{\mathrm{L}}\right)}{\partial x}=h\left(T-T_{\mathrm{L}}\right) \quad \text { at } x=1
\end{aligned}
$$

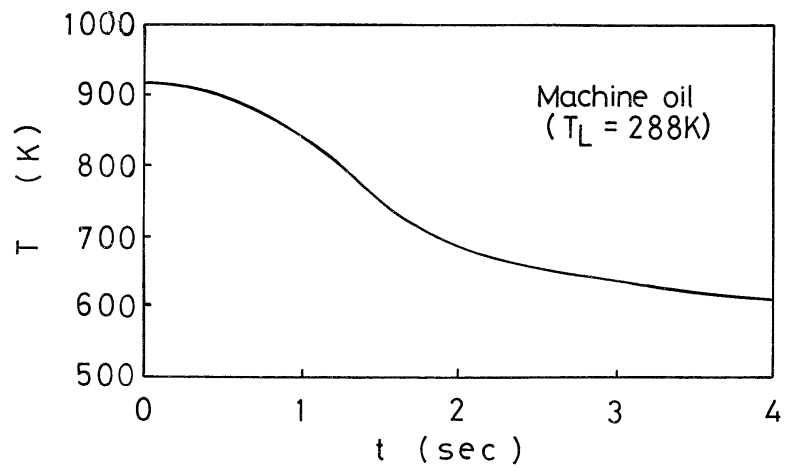

Fig. 2. Cooling curve of 68 -machine oil.

Table 1. Physical Properties of Oil

\begin{tabular}{|l|c|c|c|c|}
\hline 0il & Density & $\begin{array}{c}\text { Specific } \\
\text { heat } \\
\left(\mathrm{kg} / \mathrm{m}^{3}\right)\end{array}$ & $\begin{array}{c}\text { Thermal } \\
\text { conductivity }\end{array}$ & $\begin{array}{c}\text { Kinematic } \\
\text { viscosity } \\
(\mathrm{W} / \mathrm{mK})\end{array}$ \\
\hline Compressor 0il RP-56* & 874 & 1.14 & 0.130 & 5.58 \\
\hline Compressor 0il RP-100* & 882 & 1.12 & 0.130 & 10.1 \\
\hline Compressor 0il RP-180* & 890 & 1.12 & 0.126 & 18.5 \\
\hline 68-Machine 0il $*$ & 933 & 1.09 & 0.125 & 6.82 \\
\hline Silicone 0il YF-33-100* & 968 & 0.86 & 0.149 & 7.50 \\
\hline
\end{tabular}

*) Maruzen oil co. Itd.

**) Toshiba silicone co. Itd. 
の下で, 変数分離の方法により求められている解 ${ }^{13)}$

$$
\begin{aligned}
\frac{T-T_{\mathrm{L}}}{T_{\mathrm{i}}-T_{\mathrm{L}}}= & 2 \sum_{n=1}^{\infty}\left(\frac{\sin \lambda_{n} l}{\lambda_{n} l+\sin \lambda_{n} l \cos \lambda_{n} l}\right) \\
& \times e^{-\lambda_{n}^{2} a t} \cos \lambda_{n} x
\end{aligned}
$$

から任意の時間，位置での試験銅平板の温度を求めた。な お， $a$ は銅の温度伝導率， $T_{\mathrm{i}}$ は銅板の中心温度である。 また， $\lambda$ は

$$
\cot \lambda l=\frac{k}{h} \lambda
$$

を満足し， $k$ は銅の熱伝導率である。すなわち，中心部温 度から表層温度を推察し, その值と中心部の温度差からコ ンピューターを用いて精度を上げながら数值化していっ た. 今回は表層温度と中心部温度との差が $0.1 \%$ 以下に なったときに収束させた.

\section{3. 結果及び考察}

\section{1 各種鉱油における熱流束曲線}

液体温度が $288 \mathrm{~K}$ のとにおけるコンプレッサー油 (RP-100), マシン油, シリコーン油の熱流束と伝熱面温 度及び液温との差 $\Delta T$ を図 3 に, 熱伝達率と $\Delta T$ との関 係を図 4 に示す. Peyayopanakul とWestwater ら ${ }^{14)}$ が述 べているように, 非定常の程度により熱流束は大きく異な る. また，測定系によりその值も異なって示されることが ある.そこで, 従来のデータと比較するために沸騰水にお ける值も測定し, 橘と塩治の結果9) と比較した. 図中の破 線が橘らのデータである. 熱流束值はほぼ一致しているこ とを確認した。図 3 , 図 4 から明らかなように, 熱流束及 び熱伝達率ともマシン油, コンプレッサー油, シリコーン
油の順に小さな值を示した.シリコーン油については明確 なバーンアウト点を見いだすことはできず，他の油と異 なった傾向を示した.この点からは, シリコーン油はガラ ス板の熱強化に対して優位である.すなわち, ガラス板の 冷却中に打赻伝達率又は熱流束の変化が少ないほど, 熱強化ガラスを製作する上での管理がしやすくなるからで ある。強制対流系と組み合わせる方法も考えられてい る15)が, 実際には冷却時の破壊, ガラスの表面形状やシリ コーン油の安定性など問題があり，すぐには応用できると は言えない。なお，沸騰水についてはコンプレッサー油と ほぼ同じ最大熱流束の值であったが, 熱伝達率という観点 からみると大きく異なった値となっていることが分かる.

図 5 に動粘性係数の異なるコンプレッサー油における熱 流束の変化を示す. 動粘性係数の值が高くなると, わずか ではあるが熱流束の值が小さくなり，バーンアウト点も高 温側に移動することが分かる. 表 1 から明らかなように 動粘性係数のほかの因子すなわち, 密度, 比熱, 熱伝導率 も異なっているので, 動粘性係数の影響と一概に言うこと はできないが, ·動粘性係数も熱流束の值に影響を及ぼす重 要な因子であると推察できる.

マシン油とシリコーン油の場合における熱流束に及ぼす 液温の影響を図 6 に示す。マシン油では液油を $288 \mathrm{~K}$ から $413 \mathrm{~K}$ まで上げていくとわずかながら熱流束の值が大きく なり，バーンアウト点も低温側に移動することが分かる. シリコーン油の場合も液温を上げると似たような傾向が認 められたが，液温を変えた場合でも本実験の温度範囲では 明確なバーンアウト点を見いだすことはできなかった．

今回測定した鉱油の熱流束はエアのみの冷却と比べると

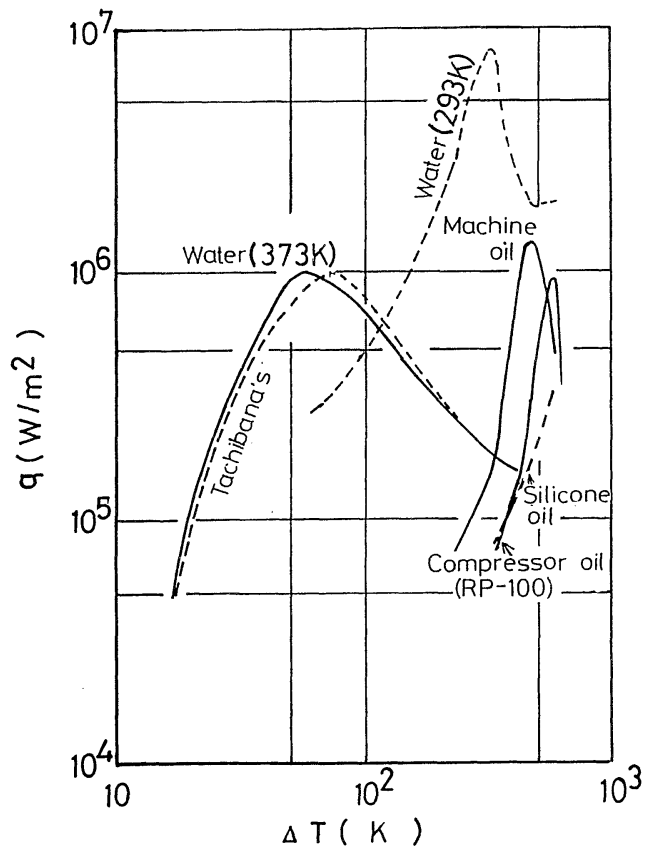

Fig. 3

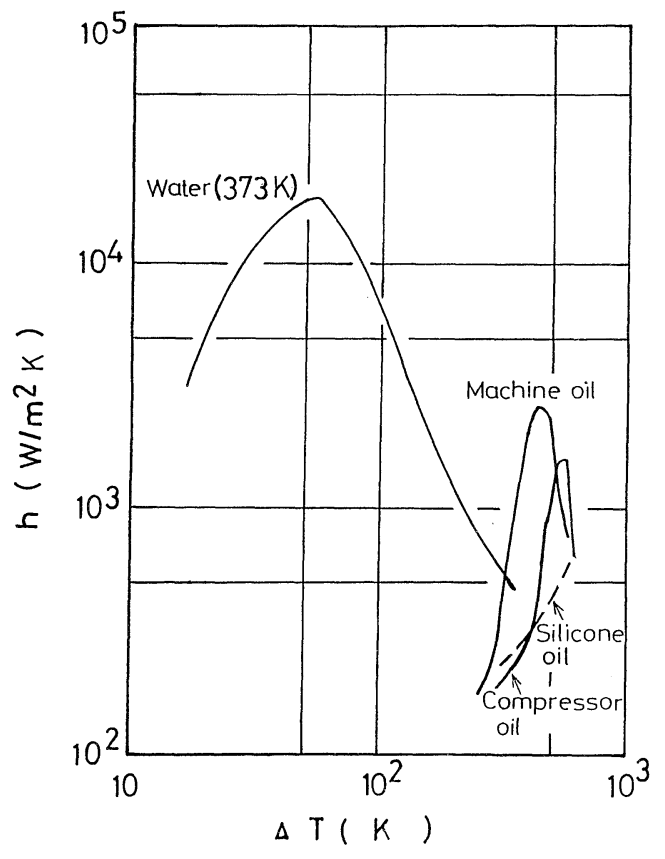

Fig. 4

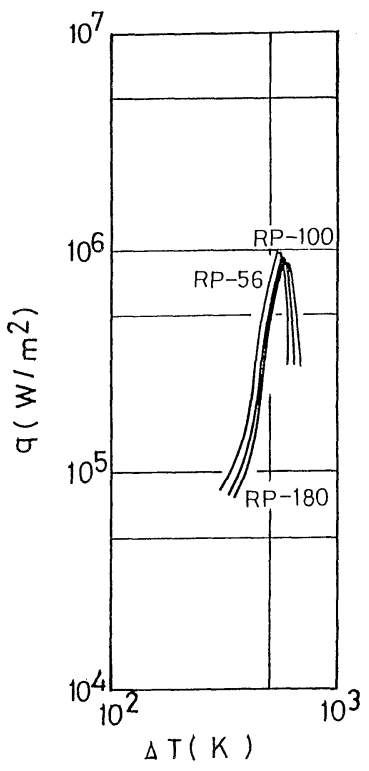

Fig. 5

Fig. 3. Heat flux vs. temperature difference.

Fig. 4. Heat transfer coefficient vs. temperature difference.

Fig. 5. Variation of heat flux with kinematic viscosity of compressor oil. 


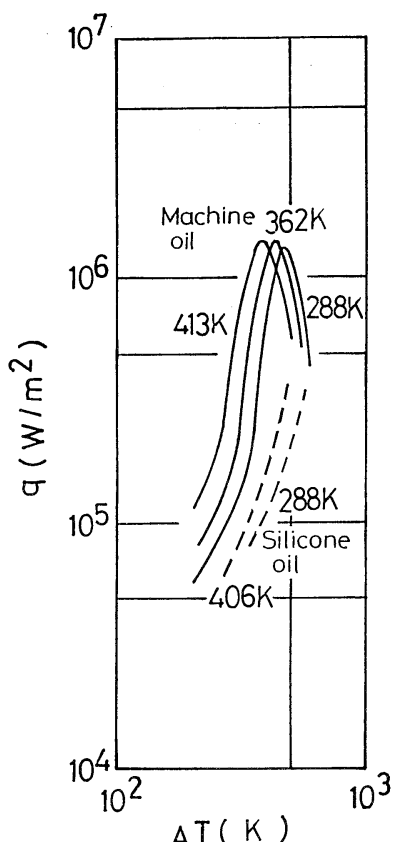

Fig. 6. Variation of heat flux with temperature of machine oil and silicone oil.

かなりその值は大きく，薄い板厚の熱強化ガラスを製作す る上で有効な範囲にある。しかし，その值は冷却時の温度 により非定常に変化し，管理は難しいレベルにあると推察 される. シリコーン油については，比較的その変化が少な いことから今回調べた他の鉱油よりも優位では山るが，す ぐに熱強化ガラスの製造に応用できるとは言い切れない面 がある。

\section{2 溶融無機塩の熱流束曲線}

溶融無機塩の熱流束曲線を図 7 に示す．溶融無機塩の場 合，水及び油と同じような型の熱流束曲線を示した。それ ぞれの熱流束の值についてもコンプレッサー油，マシン油 などの鉱油よりも小さな値を示した．熱強化ガラスの製造 に応用する場合，熱流束の值の温度依存性がコンプレッ サー油，マシン油などの鉱油よりも小さいことは好都合で ある.しかし，前述したシリコーン油と比較すると，その

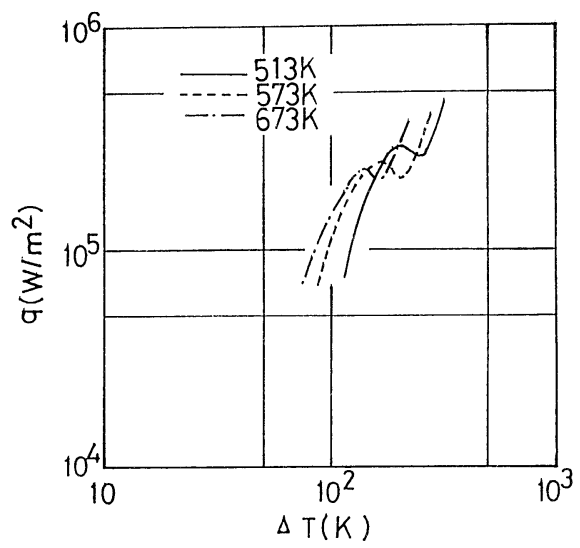

Fig. 7. Variation of heat flux with temperature of molten salt $\left(70 \mathrm{KNO}_{3}+15 \mathrm{NaNO}_{3}+15 \mathrm{NaNO}_{2}\right)$.
変化量は大きく，簡単に応用できるレベルにはない．

溶融無機塩の温度を変化させた場合には，図６に示し たマシン油及びシリコーン油とよく似た傾向を示したが, その差異はマシン油やシリコーン油の場合に比べて顕著で あった。これは，溶融無機塩の温度を変化させることによ り熱流束値の制御がしやすくなることを意味している．な お，溶融無機塩の場合においても，いわゆる沸騰曲線の様 式を示しているが，この現象が膜沸騰や核沸騰の場合にお ける気泡発生の状況の差異に起因するのか，化学変化によ り生じたものかについては今後の研究課題である。しか し，前者の場合においては熱流束値の温度依存性から，後 者においては溶融無機塩の経時劣化から製造管理が難しく なることは明らかである。

\section{3 混合油の熱流束曲線}

図 8 に2 種のコンプレッサー混合油の熱流束曲線を示 す。なお，混合油は RP-56とRP-180からなり，それぞ れの体積混合比を $2: 1$ 及び $1: 2$ にした。混合比を $2: 1$ にした場合には, 混合比を $1: 2$ にした場合と比較して, バーンアウト点はやや低温側に移動した。 しかし，各バー ンアウト点における熱流束の値については，ほとんど差異 が見られなかった．更に，RP-56あるいは RP-180のコン プレッサー油単独の場合には熱流束曲線のピークがするど い形状を示したのに対し，混合油の場合にはなだらかな形 状となっている. 動粘性係数が異なる同じタイプのコンプ レッサー油を混合すると，その混合度によってバーンアウ 卜点が変化したり, 熱流束曲線の形状が変化したりするこ とは興味深い結果である．また，2 種のコンプレッサー油 を混合した場合におけるこれらの知見は，熱強化ガラスの 製造に浸漬法を使うときに有用であろう。混合条件を選択 することにより，熱流束を適切な值にしたり熱流束值の温 度依存性を小さくできる可能性があるからである.

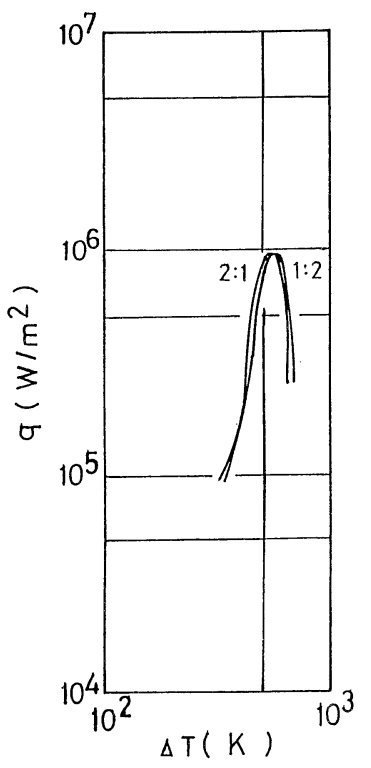

Fig. 8. Effect of volume mixing ratio on heat flux (compressor oil RP-56/RP-180=1/2, 2/1). 
2 種のコンプレッサー混合油の熱流束曲線において前述 の結果が得られた主因として，粘性そのものの影響が考え られるが, 粘性を調節するために入れている少量の添加剤 の影響も無視できず，この添加剂を加えた検討も必要であ ろう。一般には, 沸騰過程においては低沸点成分の物質移 動と気液界面温度の上昇が避けられないとされ, 混合媒体 の伝熱特性は必ず低下するとされている16)，この添加剤 が低沸点側にあるのか, 高沸点側にあるのかではその効果 は自ら異なるが，いずれにしても気液両相間の組成差から 伝熱特性は変化することになる，この添加剤については， 組成分析からその効果を推定することも可能であるが，今 後の研究課題とし, 今回の検討においては実験結果の提示 までに留めたい.

\section{4 ガラス板に対する熱伝達率又は熱流束値の妥当性} について

今回の熱伝達率又は熱流束測定は, 熱電対温度計が中心 部に固定された銅板を使って行ったが，この方法は従来か らよく使われている. 本方法の特徵は, 熱電対温度計が検 知する温度 (中心温度) と推察される表面温度の差が極め

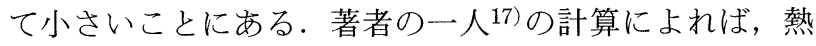
伝達率が約 $5000 \mathrm{~W} / \mathrm{m}^{2} \cdot \mathrm{K}$ の場合で表面温度と中心温度と の比は 0.98 である. 今回の測定值はそれよりも小さくかつ コンピューターによる補正で表面温度と中心温度との差を $0.1 \%$ 以下となるようにしたので, 今回得られた熱伝達率 及び熱流束の值は信頼性が高い.

しかし，ガラス板に対する熱伝達率又は熱流束を測定す るには必ずしも満足できる方法ではない．ガラスのように 熱伝導率が小さな物質に対しては, 十分な信頼性を得るこ とができない場合も多いからである．西尾18)は銅板の表 面に適当な厚さのテフロン膜を設けることにより沸騰曲線 を大幅に変化させることを実験的に確認しているし，奈良 崎 ${ }^{19)}$ は水滴の連続衝突においてガラス質の被覆層がある と高温領域での熱伝達効率が著しく大きくなることを報告 している．また．高ら ${ }^{20)}$ は種々の材料における物性值の 温度依存性が熱伝達率の計算值に著しい影響を与えると述 ベている。

今回目的としたのは薄いガラス板の熱強化を進めるうえ で，その製造条件を満足する冷却媒体の熱伝達率あるいは 熱流束の值を知ることにある，この点からいえば，今回の 測定方法はまだ不十分かもしれない。しかし，従来から測 定されてきたデータとの比較のほか，これまで測定されて いなかった種々の液体に扔ける熱流束曲線の傾向を把握す ることも重要なテーマであることを考えれば，それなりの 意義はあると思われる．今回得られた数值は，従来から測 定されてきたデータとの比較においては特に問題はないと 思われるが，ガラス板にそのまま応用できるとは断言でき ない。このような意味から，ガラス板に対しては，今回得 られた数值は参考値として判断すべきであろう.

\section{4. 結 言}

薄板強化ガラスの製造方法の冷却媒体として考えられて
いる物質の熱伝達について一連の測定を行った．市販され ている鉱油, 溶融無機塩, 鉱油の混合系について熱流束, 熱伝達率，液体温度（又は動粘性係数）などの影響を実験 的に検討したところ，今回の測定条件下に拈いて以下の知 見が得られた。

（1）シリコーン油では明確なバーンアウト点を見いた すことはできなかった．熱強化ガラスの製作上，この点で は，今回測定したほかの鉱油よりは制御しやすいように思 われるが，更に高温域での検討が必要である.

（2）動粘性係数（又は密度，熱伝導率，比熱）の異な るコンプレッサー油の熱流束を測定したところ，動粘性係 数の值が大きくなる（密度：大，熱伝導率，比熱：小）に つれて，バーンアウト点における熱流束の值は小さくな り，バーンアウト点の温度は高かった.

(3) 溶融無機塩 $\left(70 \mathrm{KNO}_{3}+15 \mathrm{NaNO}_{3}+15 \mathrm{NaNO}_{2}\right)$ に おいても熱流束曲線らしき傾向がみられた.

（4）コンプレツサー油で動粘性係数の異なる 2 種の油 を混合したところ，熱流束曲線におけるピークの形状はな だらかなものとなった。

（5）今回測定した冷却媒体は，従来から用いられてい るエアと比較して大きな熱伝達率が得られたが，熱伝達率 に対する温度依存性も認められた。これは，冷却時の熱流 束の制御はエアの場合よりも厳密に行う必要性を示してい る.

\section{文献}

1）荒谷眞一，小島英則，高山和喜，J.Ceram. Soc.Japan, 100, 1440-43 (1992).

2）荒谷眞一, 山内 豊, 楠元淳一, 高橋 清, J. Ceram. Soc. Japan, 101, 804-08 (1993)

3）高津 学, 池田周嗣, 窯協, 84, 19-23 (1976).

4) R. Gardon and J. Cobonpue, Int. Develop. Heat Transfer, ASME, 454-60 (1962).

5）荒谷畺一，村本 正, US Patent 4735646.

6）佐藤恭三, 千田好彦, 東北学院大学工学部研究報告, 23, 1-3 (1988).

7) K. Akeyoshi, E. Kanai, K. Yamamoto and S. Shima, Rept. Res. Lab., Asahi Glass Co., Ltd., 17, 23-36 (1967).

8）佐藤恭三, 日本機械学会 - 精機学会講演会講演論文集, 6466 (1980).

9）橘 藤雄, 塩冶震太郎, 日本機械学会論文集, 38, 105664 (1972).

10）佐藤恭三, 東北学院大学工学部研究報告, 20, 129-36 (1986).

11）西尾茂文，生産研究，32, 247-50（1980）。

12) 西川直宏, 高 鉄, 高津 学, 材料, 42, 507-11 (1993).

13） W. H. ギート，“基礎伝熱工学”, 丸善 (1975) pp. 260-70.

14) W. Peyayopanakul and J. W. Westwater, Int. J. Heat \& Mass Trans., 21, 1437-45 (1978).

15）佐藤恭三，日本伝熱シンポジウム講演論文集（1981）pp. 225-27.

16）藤田恭伸, 曽里田幸典, 日本伝熱シンポジウム講演論文集 (1991) pp. 94-96.

17）佐藤恭三，工学博士論文（東北学院大学, 1982).

18）西尾茂文, 日本伝熱シンポジウム講演論文集（1980）pp. 223-25.

19）奈良崎道治, 日本伝熱シンポジウム講演論文集（1980）pp. 547-49.

20）高鉄, 西川直宏, 日比雅義, 高津 学, 材料, 43, 8994 (1994). 